\title{
Disease management mitigates risk of pathogen transmission from maricultured salmonids
}

\author{
Simon R. M. Jones ${ }^{1, *}$, David W. Bruno ${ }^{2}$, Lone Madsen ${ }^{3}$, Edmund J. Peeler ${ }^{4}$ \\ ${ }^{1}$ Fisheries and Oceans Canada, Pacific Biological Station, 3190 Hammond Bay Road, Nanaimo, British Columbia V9T 6N7, Canada \\ ${ }^{2}$ Marine Scotland Science, 375 Victoria Road, Aberdeen AB11 9DB, Scotland, UK \\ ${ }^{3}$ Technical University of Denmark, National Veterinary Institute, Bülowsvej 27, 1870 Frederiksberg C, Denmark \\ ${ }^{4}$ Cefas Weymouth Laboratory, Barrack Road, Weymouth, Dorset DT4 8UB, UK
}

\begin{abstract}
Open marine net pens facilitate virus and sea lice transfer, occasionally leading to infections and outbreaks of disease in farmed salmon. A review of 3 salmon pathogens (infectious salmon anaemia virus [ISAV], salmon alphavirus [SAV] and the salmon louse Lepeophtheirus salmonis) shows that increased risk of exposure to neighbouring farms is inversely related to distance from and directly related to biomass at the source of infection. Epidemiological techniques integrating data from oceanography, diagnostics and pathogen shedding rates and viability contribute to improved understanding of pathogen transmission pathways among farms and permit the designation of areas of risk associated with sources of infection. Occupation of an area of risk may increase the likelihood of exposure, infection and disease among susceptible fish. Disease mitigation in mariculture occurs at 2 scales: area-based (coordinated stocking, harvesting and fallowing) and farm-based (vaccination, early pathogen detection, veterinary prescribed treatments and depopulation or early harvest in the event of viral disease). Collectively, implementation of mitigation measures results in virus disease outbreaks of shorter duration with lower mortality and therefore reduces the likelihood of pathogen transmission. In contrast, the mitigation of sea lice transmission is less likely to be effective in some areas due to the loss of parasite sensitivity to therapeutants and to dissemination of larval lice when parasites occur below management thresholds. For wild populations, risk of pathogen spillback is estimated from farm-based epidemiological data; however, validation, particularly for ISAV and SAV, is required using direct surveillance.
\end{abstract}

KEY WORDS: Aquaculture $\cdot$ Salmon $\cdot$ Pathogen $\cdot$ Disease $\cdot$ Interactions

\section{INTRODUCTION}

In coastal waters of the North Atlantic Ocean, finfish are reared for mariculture in open net pens. Under these conditions, farmed fish populations are exposed to pathogens (viruses, bacteria or parasites) from sources in the marine environment (e.g. wild fish) (Johansen et al. 2011) which may lead to infections (Raynard et al. 2007, Garver et al. 2013b). Generally, the movement of pathogens among susceptible populations reflects a greater connectivity in aquatic ecosystems compared with terrestrial coun-

\footnotetext{
${ }^{*}$ Corresponding author: simon.jones@dfo-mpo.gc.ca
}

terparts (Uglem et al. 2009, Green 2010), which permits various pathways of transmission and may promote changes in pathogen characteristics (Nowak 2007, Pulkkinen et al. 2010, Kurath \& Winton 2011). Occasionally, pathogens will move within and among mariculture sites, and when increases in pathogen abundance coincide with appropriate host and environmental contexts, outbreaks of disease are possible (McVicar 1997, Murray \& Peeler 2005, Bergh 2007). Outbreaks of diseases have broadened awareness of pathogen dynamics and disease progression within and among mariculture sites and have provided

(C) Fisheries and Oceans Canada, the Crown and L. Madsen 2015. Open Access under Creative Commons by Attribution Licence. Use, distribution and reproduction are unrestricted. Authors and original publication must be credited.

Publisher: Inter-Research · www.int-res.com 
much of the knowledge-base for the epidemiology of finfish diseases (Murray 2009, 2013, Salama \& Rabe 2013). As a result, mariculture incorporates disease mitigation strategies (Table 1 ) that are practised at 2 spatial scales: area-based (coordinated stocking, harvesting and fallowing) and farm-based (vaccination, early pathogen detection, veterinary prescribed treatments and depopulation or early harvest in the event of viral disease).

Endemic disease and disease outbreaks in farmed fish may be associated with an increase in pathogen spillback to wild fish stocks (Kurath \& Winton 2011). The potential threat of pathogen interactions between mariculture and wild fish has been considered for some time (Håstein \& Lindstad 1991, McVicar 1997, Hedrick 1998) and more recently has been refined in reviews, models and risk assessments (Peeler et al. 2007, Johansen et al. 2011). However, in contrast to mariculture, the epidemiology of disease in wild finfish is poorly understood, and information on which to make judgments about pathogen spillback is sparse. There is evidence that the distribution of some pathogens in wild populations is correlated with the proximity to mariculture (Wallace et al. 2008); however, diseases are rarely observed in wild marine finfish (Hedrick 1998, Noakes et al. 2000, Bergh 2007, Riley et al. 2008, Johansen et al. 2011). Nevertheless, the potential importance of spillback from farmed to wild salmon has to be considered

Table 1. Measures to mitigate pathogen introduction, dissemination and consequences in mariculture

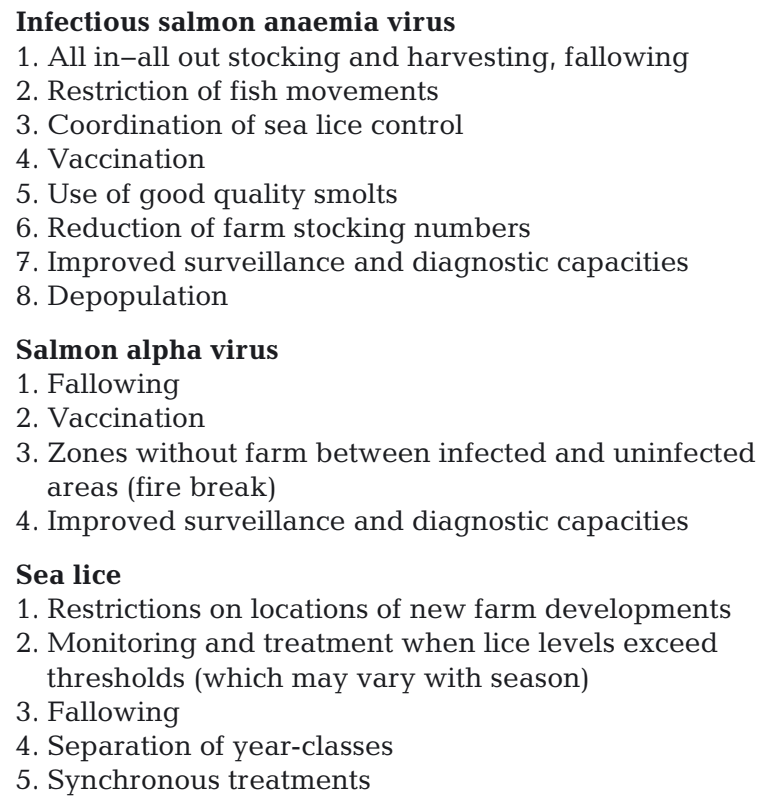

given that in several regions for salmon mariculture the biomass of farmed salmon considerably outweigh the wild population. In Norway, 400 million salmon are reared each year compared with $\sim 400000$ returning adult salmon (Thorstad \& Forseth 2010). These data, combined with the known risk of escapees and the close contact of wild and farmed salmon suggests that farmed salmon could act as an important reservoir of infection for wild salmon.

The goal of this paper is to assess the extent to which current epidemiological knowledge informs our understanding on the risks and consequences of pathogen transmission from farmed salmon populations. We consider these risks and consequences to be relevant both to wild and maricultured populations. As Atlantic salmon Salmo salar and rainbow trout Oncorhynchus mykiss constitute over $95 \%$ of the biomass of maricultured finfish in the northeast Atlantic Ocean (FAO 2012), the present paper focuses on 3 pathogens which cause diseases of considerable economic impact in salmon mariculture. For each of infectious salmon anaemia virus (ISAV), salmon alpha virus (SAV) and the salmon louse Lepeophtheirus salmonis, we review occurrence in wild populations and epidemiological considerations including mitigation practices in mariculture and evidence of spillback. For each disease, we then provide a qualitative risk assessment according to 3 pathways of effects (introduction, dissemination from farm, consequences) and estimate the differential collective impacts of disease mitigation strategies.

\section{MATERIALS AND METHODS}

Pathways for pathogen interactions between wild and farmed populations are illustrated in Fig. 1. A risk analysis framework similar to that described earlier for aquatic animal health management (Peeler et al. 2007) is used to assess for each pathogen the effect of farm-based disease mitigation practices (Table 1) on the likelihood and uncertainty of each effects pathway and the consequences of pathogen spread. Definitions for descriptors of likelihood and uncertainty are given in Tables $2 \& 3$.

\section{Infectious salmon anaemia virus (ISAV)}

Introduction

Infectious salmon anaemia (ISA) was first reported in farmed Atlantic salmon in Norway in 1984 (Thorud 


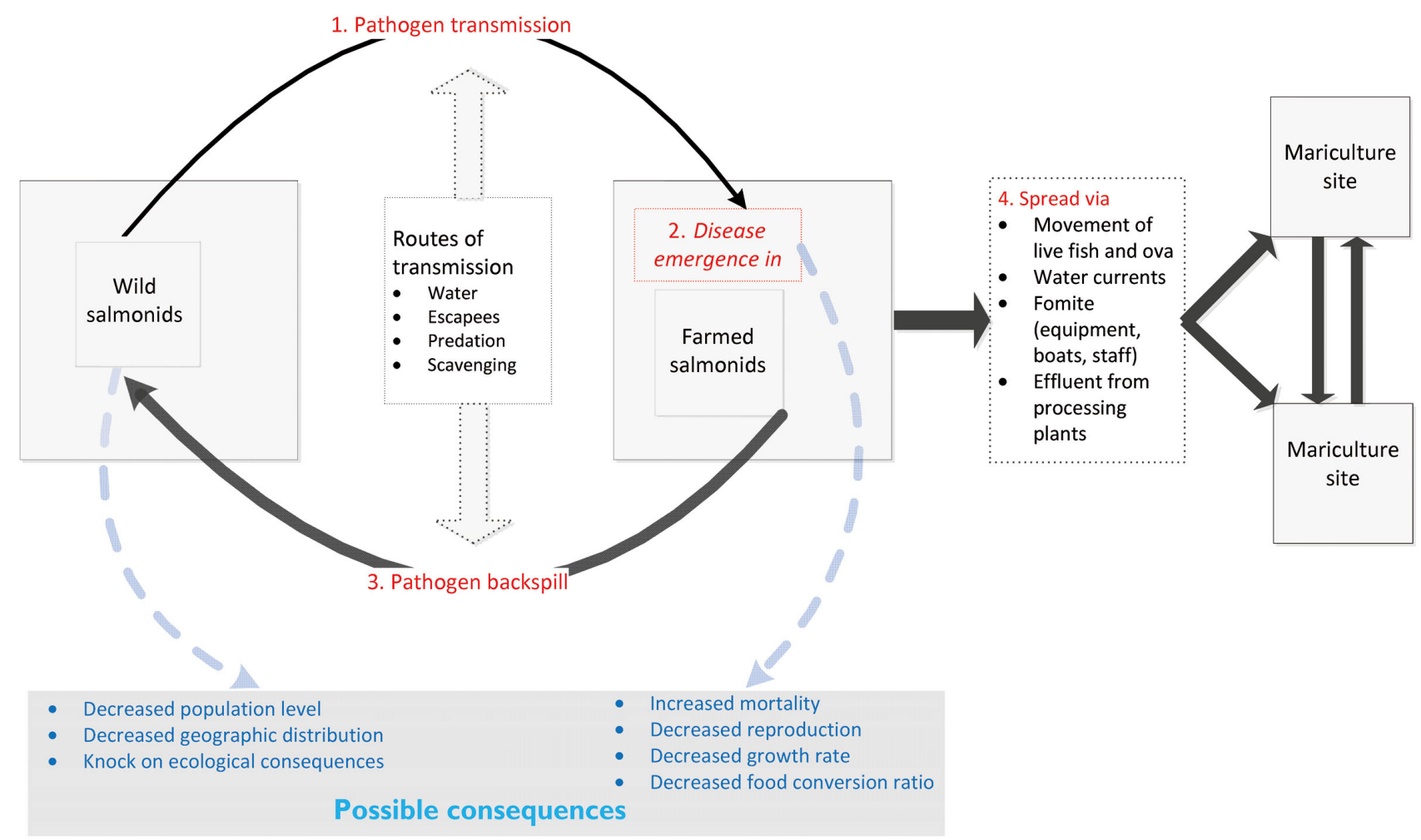

Fig. 1. Routes and consequences of pathogen interactions between farmed and wild salmonids (numbers indicate temporal sequence of processes driving emergences: 3. and 4. may occur simultaneously)

Table 2. Definitions of levels of uncertainty used in risk assessment (EFSA 2006)

\begin{tabular}{|c|c|}
\hline Uncertainty & Definition \\
\hline Low & $\begin{array}{l}\text { - Solid and complete data available; strong } \\
\text { evidence in multiple references with most } \\
\text { authors coming to the same conclusions, or } \\
\text { - Considerable and consistent experience } \\
\text { from field observations }\end{array}$ \\
\hline Medium & $\begin{array}{l}\text { - Incomplete, or only some data available; } \\
\text { evidence provided in small number of } \\
\text { references; authors' or experts' conclusions } \\
\text { vary, or } \\
\text { - Limited evidence from field observations, } \\
\text { or } \\
\text { - Solid and complete data available from } \\
\text { other species which can be extrapolated } \\
\text { to the species being considered }\end{array}$ \\
\hline High & $\begin{array}{l}\text { - Scarce or no data available; evidence } \\
\text { provided in unpublished reports, or } \\
\text { - Few observations and personal communi- } \\
\text { cations, and/or } \\
\text { - Authors' or experts' conclusions vary } \\
\text { considerably }\end{array}$ \\
\hline
\end{tabular}

\& Djupvik 1988) and since then in eastern Canada and the USA, Scotland, Chile and the Faroe Islands (Christiansen et al. 2011, Rimstad et al. 2011, Lyngstad et al. 2013). The disease is characterized by anaemia, haemorrhage and necrosis in several organs and is caused by ISAV. ISAV belongs to the genus Isavirus within the family Orthomyxoviridae. Different strains or genotypes of the virus occur. The low virulent variant (ISAV-HPR0) is found in apparently healthy wild and farmed fish, and Kibenge et

Table 3. Definitions of levels of estimated likelihood

\begin{tabular}{|ll|}
\hline Likelihood & Definition \\
\hline Rare & $\begin{array}{l}\text { Event may only occur in exceptional } \\
\text { circumstances }\end{array}$ \\
Unlikely & Event could occur but is not expected \\
Moderate & Event might occur at some time \\
Likely & $\begin{array}{l}\text { Event will probably occur in most } \\
\text { instances }\end{array}$ \\
Almost certain & $\begin{array}{l}\text { Event is expected to occur in most } \\
\text { instances }\end{array}$ \\
& \\
\hline
\end{tabular}


al. (2012) list 3 hypotheses to explain the relationship between low virulent and virulent strains: ISAVHPR0 in wild fish is ancestral to virulent ISAV variants (Rimstad et al. 2011), virulent ISAV mutates to a less virulent form, and HPR0 is the original consensus sequence of all HPR-deleted sequences during virus replication in a cell. However, HPR0 strains are also detected late during disease outbreaks and persist long after the disease has been eradicated (Christiansen et al. 2011, Kibenge et al. 2012). Fish are infectious well before clinical signs are observed (Totland et al. 1996) and shed viral particles within $3 \mathrm{~d}$ of initial infection via faeces, urine and skin mucus (Lyngstad et al. 2013).

The transmission of ISAV among Atlantic salmon is primarily horizontal in both freshwater and seawater (Totland et al. 1996, Jones \& Groman 2001, Lyngstad et al. 2013), although vertical transmission has not been ruled out (Thorud \& Djupvik 1988, Melville \& Griffiths 1999, Marshall et al. 2014). ISAV occurs in gonadal tissue in spawning salmon (Nylund et al. 2003, 2007), and there is evidence that the virus was introduced to Chile in association with salmon ova (Vike et al. 2009).

Wild reservoirs and extent of surveillance

In addition to Atlantic salmon, the virus replicates in brown trout Salmo trutta and Arctic charr Salvelinus alpinu) (Jones et al. 1999a, Kibenge et al. 2004). Atlantic herring Clupea harengus and American eel Anguilla rostrata may also be asymptomatic carriers (Totland et al. 1996, Devold et al. 2000, Kibenge et al. 2004). Pollock Theragra chalcogramma do not appear to be a reservoir for the virus despite wild populations having close contact with cultured Atlantic salmon (McClure et al. 2004). Pacific salmon (Oncorhynchus keta, O. tshawytscha, O. kisutch and O. mykiss) appear resistant to ISAV infections; however, the virus has been re-isolated from experimentally infected chum and coho salmon and from steelhead, suggesting these species are susceptible under certain circumstances (Rolland \& Winton 2003). Relatively little research has been conducted on the prevalence and maintenance of ISAV infections in wild fish populations including those adjacent to affected Atlantic salmon mariculture sites. Serum antibodies to ISAV were measured in returning Atlantic salmon from the Connecticut and Penobscot Rivers in the eastern USA, suggesting the fish had previously been exposed to the virus (Cipriano 2009). The virus was isolated from sea trout in Scotland (Raynard et al. 2001), and there was evidence of viral genomic RNA in Atlantic salmon parr and adults and in non-migratory and anadromous brown trout collected either close to farm operations or in rivers distant from farm operations, in the absence of clinical disease (Raynard et al. 2001). In Norway, brown trout collected from rivers were found to harbour the highest prevalence of the virus, while Atlantic salmon showed low prevalence of the virus (Plarre et al. 2005). No fish showed clinical signs of infection, and ISAV was not cultured from any of the samples tested but could be detected after a few weeks in disease-free salmon injected with tissue homogenates from RT-PCR-positive wild fish (Plarre et al. 2005). Therefore, Atlantic salmon, brown trout and sea trout are candidate reservoir species of ISAV HPR0 (EFSA 2012).

Epidemiological considerations in mariculture

Risk categorizations and themes for pathogen introduction into marine salmon farms have been evaluated by Oidtmann et al. (2013). Lyngstad et al. (2008, 2013) list the characteristics relevant to assessment of pathways of horizontal transmission for ISAV including live fish movements and egg movement, exposure via water, on-site processing, short distance mechanical transmission as well as distance independent mechanical transmission. The risk of ISAV dissemination from infected to adjacent farms is related to the salmon biomass and host density at the infected site (Ögüt et al. 2005, Hammell \& Dohoo 2005, McClure et al. 2005, Salama \& Murray 2011, 2013) and inversely related to seaway distances among the farms (Mardones et al. 2009, 2011, Aldrin et al. 2011, Murray 2013). The latter factor is linked to local hydrodynamic conditions, which influence the rate and direction of virus dispersal (Gustafson et al. 2007, Salama \& Murray 2013), but generally, a short seaway distance to an ISA site is an important risk factor. ISAV might be spread by infected biological material including animal waste or discharge from slaughtering (Lyngstad et al. 2013), and this is directly related to the biomass of infected stock harvested (Munro et al. 2003). Mardones et al. (2014) found that multiple generations on a farm, mean smolt weight at stocking $>120 \mathrm{~g}$, farm area and increased number of shipments entering a farm were associated with reduced time to infection, whereas time-to-infection was longer for farms located farther away from an ongoing ISAV outbreak. Transport of infected fish in well boats or sharing of personnel and equipment among sites are important risk factors, particularly for transmission 
over greater distances (Murray et al. 2002, Murray 2013). Outbreaks of ISA in Norway, Scotland, eastern Canada and the USA and Chile have led to the establishment of exclusion or management zones defined by clusters of sites sharing tidal excursions, embayments or other common waterways (Mardones et al. 2011, Murray 2013). Such disease management areas (DMAs) can be effective at preventing disease emergence, even with some transfer to neighbouring areas, if the number of long-distance contacts is kept to a minimum, and fallowing is synchronized (Werkman et al. 2011, Murray 2013).

\section{Mitigating factors and spillback}

The establishment of more stringent on-farm and among-farm biosecurity measures have reduced the risk of infection as indicated by the reduced longevity, reduced mortality and spatial limitations of more recent outbreaks (Murray et al. 2010, Mardones et al. 2014). Maintaining fish in good health may reduce their susceptibility to low virulent strains and thus lower the rate of new outbreaks (Lyngstad et al. 2011). Rapid removal of sick or dead stock is also effective in limiting virus transmission (Jarp \& Karlsen 1997). Coordinated fallowing within management areas combined with risk-based surveillance lessens the likelihood that virulent ISAV will persist and re-establish (Murray et al. 2010). In Chile, disease control measures introduced in 2009 (summarized in Table 1) contributed to the recovery of the industry after the occurrence of ISA (Mardones et al. 2014). Ritchie et al. (2009) suggested that different ISAV strains will pose different risks following infection and showed that survivors of an earlier infection had greater resistance to subsequent infection. Similarly, mortality and virus levels in salmon previously exposed to a low virulence ISAV strain were lower following challenge with a high virulence strain compared with naive controls (LeBlanc et al. 2012). Vaccination against ISA may be feasible (Jones et al. 1999b). While such management actions will mitigate the risk of virus transmission, there are no data on transmission of ISAV to wild fish. Occurrence of the HPR0 genotype in wild salmonids indicates that a reservoir of infection exists outside the farmed salmon population (EFSA 2012). Lyngstad et al. (2011) found the low virulent genotype to be frequently present in farmed Atlantic salmon in Norway and concluded that this strain transitioned into virulent genotypes causing solitary outbreaks or local epidemics. Although there is a theoretically higher risk for wild fish to acquire the infection the closer they are to an infected site, failure to detect such patterns of infection likely reflects the limited effort to survey these populations (Lyngstad et al. 2013).

\section{Salmon alpha virus (SAV)}

\section{Introduction}

Pancreas disease (PD) was first reported from farmed Atlantic salmon in Scotland (Munro et al. 1984). A similar condition named 'sleeping disease' (SD) was subsequently described from freshwaterreared rainbow trout (Boucher \& Baudin-Laurencin 1996). PD represents a chronic condition with associated mortality in farmed salmon and trout and consequently is of economic importance for farmed fish in Ireland, Norway and Scotland (Rodger \& Mitchell 2007, Aunsmo et al. 2010, Jansen et al. 2014). Both diseases are caused by infection with SAV in the family Togaviridae (Weston et al. 1999), also known as salmon pancreas disease virus. Six SAV subtypes have been distinguished using phylogenetic analysis with partial E2- and nsP3-gene sequence data (Fringuelli et al. 2008), providing evidence that some subtypes are dominant in certain geographical regions. Following infection, virus RNA persists in tissues for extended periods (Andersen et al. 2007, Christie et al. 2007, Graham et al. 2010, Jansen et al. 2010), posing a possible risk to healthy fish. Salmonid alphaviruses are transmitted horizontally (Boucher et al. 1995) and have been detected in the salmon louse Lepeophtheirus salmonis by PCR (Petterson et al. 2009), but in this case viral replication in lice and consequent transfer of the virus to a new host has not been demonstrated. This is in contrast to the 26 enveloped mammalian alphaviruses that cause disease in humans and domestic animals, and which require mosquitoes or other haematophagous arthropods to serve as vectors (Brown \& Condreay 1986). The identification of potential vectors for SAV has been highlighted as an area for investigation, and knowledge in this area would improve management and understanding regarding risk and infection (McLoughlin \& Graham 2007).

Wild reservoirs and extent of surveillance

In Scottish waters, long rough dab Hippoglossoides platessoides, common dab Limanda limanda and plaice Pleuronectes platessa were identified as possible reservoirs of SAV based on the detection of low 
levels of virus RNA in pooled tissues (Snow et al. 2010). Virus subtype V was subsequently isolated into cell culture from common dab (Bruno et al. 2014). Three of the $6 \mathrm{SAV}$ subtypes were identified in dab in a locality remote from salmonid aquaculture, strongly implicating dab as a non-salmonid reservoir of the virus. Fringuelli et al. (2008) reported identical sequences at separate farm sites over several years, implying that this is a slowly evolving virus. This is supported by a virus evolution study by Karlsen et al. (2014), which concluded that all 6 subtypes of SPDV diverged prior to the $20^{\text {th }}$ century and earlier than the first introduction of farmed rainbow trout into Europe. SAV positive tissues were detected by real-time RTPCR and sequencing in common dab, plaice and megrim Lepidorhombus whiffiagonis from the Irish and Celtic Seas (McCleary et al. 2014). A very low prevalence of SAV subtype I was reported in common dab and plaice, except for 1 haul in Dublin Bay, Ireland where $25 \%$ of common dab were SAV positive.

Epidemiological considerations in mariculture

SAV II is the dominant subtype from Atlantic salmon reared in the Shetland Isles, Scotland, whereas salmon from the northeast of Scotland and the Western Isles show subtype $\mathrm{V}$ as dominant (Graham et al. 2012). Subtypes I, IV, V and VI have been isolated from Atlantic salmon in Scotland and Ireland (Weston et al. 2005, Fringuelli et al. 2008) and subtype II from rainbow trout in the UK and continental Europe. The subtype III is restricted to farmed Atlantic salmon in Norway. Recently, a subtype II has also been reported from Norwegian farmed salmon (Hjortaas et al. 2013, Jansen et al. 2014). There is also evidence that subtypes traditionally observed in one environment are now identified in new areas, for example, the finding of SAV II strains in saltwater reared Atlantic salmon (Graham et al. 2012) and SAV I strains occurring in freshwater salmonids (Lester et al. 2011). Statistical models regarding the most likely route of transmission of SAV among farmed fish suggest passive drift of virus in the water (Viljugrein et al. 2009, Stene et al. 2014). Horizontal transmission of the virus affects the probability of a disease outbreak in a single cohort (McLoughlin et al. 1996, Kristoffersen et al. 2009, Viljugrein et al. 2009). Evidence of vertical transmission of SAV III was not found in a study by Kongtorp et al. (2010). Madhun et al. (2014) detected SAV and piscine reovirus in recently escaped salmon in Norway, highlighting the potential contribution of escapees in virus transmission to other local salmon farms.
Mitigating factors and spillback

The available information indicates that SAV is transmitted among mariculture populations and that movement of the virus between marine reservoirs and mariculture populations is bidirectional. Fallowing of farm sites reduces or limits the build-up of infectious agents, a practice that is required in many countries. However, despite fallowing, SAV has re-emerged at some farms following restocking (McLoughlin et al. 2003), and persistence of the virus in sediments may serve as a source of infection. Experimental work has shown that SAV can survive for $\sim 6 \mathrm{~d}$ at $10^{\circ} \mathrm{C}$ in sterile saltwater with organic loading (Graham et al. 2007). This suggests that the virus is sufficiently viable in the aquatic environment to be useful for modelling, as assumed by Viljugrein et al. (2009). Phylogenetic data of SAV subtype IV are consistent with a history of repeated transmission between dab and salmon. Common dab can move into brackish waters and then enter freshwater river systems in coastal areas (Elliott et al. 1990); hence, they could encounter subtypes other than those frequently attributed to marine salmon as reported by Lester et al. (2011). Graham et al. (2006) reported virus-neutralising serum antibodies in saithe Pollachius virens, a species commonly found in the vicinity of sea cages, but no disease was recorded. This indicates the possibility of inter-species transmission of SAV between wild and farmed fish. The precise role of common dab as a natural host with potential to transmit infection to farmed fish is not known, particularly if the virus is self-sustaining in aquaculture through farming practices (Kristoffersen et al. 2009, Bruno et al. 2014). Interestingly, Karlsen et al. (2014) suggest that SAV subtypes diverged prior to fish farming and therefore must have been associated with a marine reservoir. Mitigation to contain SAV in endemic regions also includes vaccination (Bang Jensen et al. 2012, Karlsen et al. 2012).

SAV occurs at low levels in wild non-salmonid fish and there is no evidence that infections are associated with disease. Overall the conditions that promote epidemics and disease occurrence in aquaculture may not occur for wild fish, thus limiting the occurrence of clinical disease and its effects on wild fish.

\section{Sea lice}

Introduction

Sea lice are parasitic copepods which are ubiquitous and inevitable pests of maricultured salmon, with an 
estimated annual global cost to industry of $€ 300$ million (Costello 2009). In the northern hemisphere, the salmon louse L. Salmonis is the largest and most aggressive species affecting salmon and therefore the target of management and treatment. Sea lice life cycles include a free-living phase, consisting of first and second stage nauplii and infective copepodids, and a parasitic phase consisting of 2 chalimus stages, 1 or 2 preadult stages and adults (Hamre et al. 2013). The free-living stages are non-feeding and dispersive and their longevity is defined by endogenous lipid and ambient temperature (Cook et al. 2010). The extent of dispersion during early larval development is largely determined by currents in the ambient seawater (Tully \& Nolan 2002). Host-seeking and attachment by the copepodid is facilitated by anatomical, physiological and behavioural traits (see Mordue \& Birkett 2009). In the absence of treatment, high host densities combined with appropriate environmental conditions support rapid growth in the size of the parasite population with associated scale loss, skin ulceration and haemorrhage (Brandal \& Egidius 1977, Wootten et al. 1982, Johnson et al. 2004).

\section{Wild reservoirs and extent of surveillance}

Infestations with $L$. salmonis have been reported from anadromous salmonids for over $300 \mathrm{yr}$ (Torrissen et al. 2013), and an historical perspective on scientific surveillance efforts in the North Atlantic and Pacific Oceans is provided by Pike \& Wadsworth (1999). Recent research supports the view that the parasite is prevalent and abundant on salmonids throughout the northern hemisphere with some variation among host species. In Ireland, over $93 \%$ of 928 returning adult Atlantic collected off the Irish coast between 2004 and 2011 were infested with an average of nearly 12 L. salmonis per fish (Jackson et al. 2013b). In Scotland, all 94 adult salmon caught over 2 yr were infested with mean intensities of 26.1 to $28.7 \mathrm{~L}$. salmonis per fish (Todd et al. 2000). In the northeast Pacific Ocean, more than $98 \%$ of returning adult salmon had mixed infestations with L. salmonis and Caligus clemensi and the mean intensity of adult female $L$. salmonis ranged among species from 1.6 to 8.5 (Beamish et al. 2005). In addition to the high prevalence, a common feature of infections on returning Pacific salmon is that most parasites are motile (preadults or adult stages). An autumn rise in sea lice abundance in mariculture has been associated with the seasonal return of infested adult Pacific salmon during their spawning migrations (Beamish et al. 2007, Saksida et al. 2007, Marty et al. 2010).

\section{Epidemiological considerations in mariculture}

Outbreaks with L. salmonis occurred on farmed salmon in Norway in the 1960s, in Scotland in the 1970s and in eastern Canada in the 1990s (Jones 2009). Thus, a need for management and treatment options for L. salmonis arose prior to a clear understanding of the epidemiology of the parasite. Early investigations explored the importance of parameters useful for farm-based parasite management, including level and type of treatment, cage volume, temperature effects on development, salinity, current speed, tidal flushing time, history of sea lice infections and fallowing (Bron et al. 1993, Revie et al. 2002, 2003, 2005, Heuch et al. 2003, 2009, McKenzie et al. 2004, Stien et al. 2005, Saksida et al. 2007, Lees et al. 2008). Host biomass or density is an important mariculture variable in some Norwegian fjords in which a large number of farms occupies a relatively small volume of water (Bjørn et al. 2011, Jansen et al. 2012). Mathematical models expanded on the earlier observations and estimated the dispersal of sea lice larvae according to the speed and direction of water flow in coastal ecosystems (Murray \& Gillibrand 2006, Gillibrand \& Kate 2007, Stucchi et al. 2011, Salama et al. 2013, Asplin et al. 2014). Aldrin et al. (2013) used Norwegian data to model the expected abundance of lice at a farm as a function of 1 molagged abundance at the same farm, at neighbouring farms or at other non-identified sources. The model assumed lice populations followed a zero-inflated negative binomial distribution and found that the same farm accounted for two-thirds of the expected abundance, neighbouring farms accounted for slightly less than one-third and other sources, $\sim 6 \%$ of the observed abundance (Aldrin et al. 2013). Analysis of data from Chilean farmed salmon infected with another parasitic copepod, Caligus rogercresseyi, found a significant relationship with infections on neighbouring farms during the preceding 2 wk (Kristoffersen et al. 2013). Direct measures of salmon louse infestation pressure using sentinel fish and surveillance of wild populations (Bjørn et al. 2011, Middlemas et al. 2013, Serra-Llinares et al. 2014) may be useful in validating the models. Together these studies are consistent with the 'neighbour' concept described in Aldrin et al. (2013) and indicate that elevated risk of salmon louse infestation can extend $30 \mathrm{~km}$ from a farm, as shown earlier (Krkošek et al. 2005, Jansen et al. 2012, Middlemas et al. 2013). 


\section{Mitigating factors and spillback}

Increased abundances of $L$. salmonis have repeatedly been observed on wild salmonids in coastal regions associated with salmon mariculture in Ireland, Norway and western Canada (Tully \& Whelan 1993, Tully et al. 1999, Bjørn et al. 2001, Bjørn \& Finstad 2002, Morton et al. 2004, Marty et al. 2010, Middlemas et al. 2010, 2013). Accordingly, Norway has implemented 'Temporary Protected Zones' and 'Norwegian Salmon Fjords' (Heuch et al. 2005, Bjørn et al. 2011, Serra-Llinares et al. 2014), in which there are restrictions to the development of new farms, and established farms must follow mandatory actions including scheduled reporting of lice numbers, synchronized treatments and fallowing within management areas to maintain lice levels below required limits (Bjørn et al. 2011, Ritchie \& Boxaspen 2011). While larger protected areas can be effective in minimising levels of $L$. salmonis on farms, some protected areas may be too small due to increased local biomass densities or to increased external influences (Serra-Llinares et al. 2014). Other jurisdictions have implemented strategies to manage sea lice. In British Columbia (western Canada), the Sea Lice Management Strategy adopted in 2003 requires management action when total motile (adult and preadult) $L$. salmonis abundances exceed 3 per fish during the juvenile pink salmon juvenile migration between March and July (Saksida et al. 2011). Ireland has maintained a national Sea Lice Monitoring Programme for salmonid mariculture since 1991 (O'Donohoe et al. 2013) (O'Donohoe et al. 2013, p. 3). Data are published annually and serve in part 'to provide management information to drive the implementation of control and management strategies'. The 5 principal components of the programme are to separate generations, to fallow sites annually, to harvest early 2 -sea-winter fish, to use targeted and synchronous treatment regimens and to use agreed husbandry practices.

Temporal patterns in the abundance of planktonic L. salmonis nauplii and copepodids in coastal and off-shore regions of a Scottish loch are correlated with treatment or relocation actions of farmed salmon within the same loch (McKibben \& Hay 2004, Penston et al. 2008, Penston \& Davies 2009, Murray et al. 2011, Penston et al. 2011). Similarly, infection pressure on sentinel salmon smolts is related to the abundance of ovigerous $L$. salmonis on adjacent populations of cultured salmon (Bjørn et al. 2011, Pert et al. 2014). Conversely, the coordinated proactive application of salmon louse treatments, regardless of louse abundance, was associated with reduced abun- dances on juvenile Pacific salmon that migrate in adjacent waterways in British Columbia (Jones \& Hargreaves 2009, Peacock et al. 2013, Rogers et al. 2013). Collectively, these studies recognise that spatial distributions of infective L. salmonis larvae near mariculture sites are governed by physical processes such as wind forcing which act locally and drive water flow (Amundrud \& Murray 2009), and by the application of sea lice management strategies. Importantly, the failure of many treatment options due to reduced sensitivity within louse populations indicates a need for alternative management strategies (Jones 2009, Torrissen et al. 2013, Helgesen et al. 2014).

Evidence for population-level effects related to spillback

The possibility that $L$. salmonis adversely impacts wild salmonid populations stems from evidence of disease caused by severe infestations on individual salmon combined with the observations that many populations of Atlantic salmon and sea trout have been declining throughout the North Atlantic Ocean since the late 1980s (Parrish et al. 1998, Chaput 2012). The extent to which the negative health effects of sea lice on individual juvenile salmon may be extrapolated to measurable changes in salmon population abundance has been explored using mathematical models (Krkošek et al. 2007, 2011) or meta-analyses (Ford \& Myers 2008). Sea trout smolts may be particularly vulnerable because they occupy coastal marine habitats and therefore may be at greater risk of exposure associated with mariculture. In the Hardangerfjord, Norway, where annual production of maricultured salmon is over $80000 \mathrm{t}$ (Skaala et al. 2014a), sea trout have been infested with potentially lethal intensities of $L$. salmonis in 2008, 2010 and 2012 (Serra-Llinares et al. 2014). In this region there has been a decline in the number of mature sea trout in the River Guddalselva between 2000 and 2011 (Skaala et al. 2014b). Similarly, declining sea trout populations in western Ireland were associated with elevated sea lice infestations and proximity to mariculture (Tully et al. 1999). Effects of sea lice on Atlantic salmon populations have been investigated by treating smolts with emamectin benzoate and comparing the survival of treated and untreated salmon. Emamectin benzoate is toxic to $L$. salmonis, and these studies assumed that differences in survival are due to sea lice-associated mortality. The results of 
similar long-term studies conducted in Ireland (Jackson et al. 2013a) and Norway (Skilbrei et al. (2013) are summarised in Torrissen et al. (2013). Both studies reported overall marine mortality of $95 \%$ or greater regardless of treatment, and there was considerable variability in the apparent efficacy of treatment among years and release dates. Nevertheless, the likelihood that treatment increased salmon survival, expressed as an odds-ratio, was calculated to range from $1.14: 1$ to $1.17: 1$ in the Irish and Norwegian studies, respectively. A meta-analysis of the Irish and Norwegian data, including those of Gargan et al. (2012), reported increased survival among treated salmon with an odds ratio of 1.29:1 (Krkošek et al. 2013). Although there is an ongoing debate regarding the quantitative outcome, these studies provide a glimpse into the magnitude of sea lice effects in wild salmonid populations. They also emphasise the challenges associated with attempting to quantify the incremental impact of a parasite within a population already experiencing >95\% mortality.

\section{Risk assessment}

The likelihood that disease mitigation strategies adopted by salmon mariculture influence the transmission of ISAV, SAV and L. salmonis, as conceptualised in Fig. 1, is summarised in Table 4. In the absence of mitigation, there is high confidence in the likelihood that zones of ISAV infectivity will extend beyond farms or farm clusters (Werkman et al. 2011), resulting in elevated risk of exposure among adjacent susceptible species. Mitigation of infectious salmon anaemia, including biosecurity measures, early detection and depopulation, is associated with a reduced likelihood of virus acquisition from neighbouring farms, resulting from reduced virus transmission by water, fish-to-fish contact or by biological or anthropogenic vectors (Table 4A). Conversely, mitigation practices in mariculture are unlikely to influence transmission of the virus from a wild reservoir. Similarly, while mitigation is expected to lessen the likelihood of ISAV spillback, the absence of effective surveillance of wild populations elevates the

Table 4. Estimates of likelihood and uncertainty surrounding the effects of mitigation on risk pathways associated with the introduction, dissemination and consequences of (A) infectious salmon anaemia virus, (B) salmon alphavirus and (C) the salmon louse Lepeophtheirus salmonis in mariculture. See Table 1 for mitigation measures

\begin{tabular}{|c|c|c|c|c|c|}
\hline \multirow{2}{*}{ Pathway of effect } & \multirow{2}{*}{ Description } & \multicolumn{2}{|c|}{ With mitigation } & \multicolumn{2}{|c|}{ Without mitigation } \\
\hline & & Likelihood & Uncertainty & Likelihood & Uncertainty \\
\hline \multicolumn{6}{|c|}{ (A) Infectious salmon anaemia virus } \\
\hline \multirow[t]{2}{*}{ Introduction } & Infection on farm derived from neighbouring farm & Unlikely & Low & Likely & Low \\
\hline & Infection on farm derived from wild reservoir & Unlikely & High & Unlikely & High \\
\hline \multirow[t]{4}{*}{ Dissemination from farm } & Water (including mucous, faeces) & Unlikely & Low & Likely & Low \\
\hline & Fish-to-fish contact (including escaped fish) & Unlikely & Medium & Moderate & Medium \\
\hline & Biological vectors (parasites, birds, etc.) & Unlikely & Medium & Moderate & Medium \\
\hline & Equipment and personnel & Unlikely & Low & Likely & Low \\
\hline \multirow{2}{*}{ Consequences } & Spillback infection in wild host & Unlikely & High & Likely & High \\
\hline & Disease in wild population & Unlikely & High & Unlikely & High \\
\hline \multicolumn{6}{|l|}{ (B) Salmon alphavirus } \\
\hline \multirow[t]{2}{*}{ Introduction } & Infection on farm derived from neighbouring farm & Unlikely & Low & Likely & Low \\
\hline & Infection on farm derived from wild reservoir & Unlikely & Medium & Unlikely & Medium \\
\hline \multirow[t]{4}{*}{ Dissemination from farm } & Water (including mucous, faeces) & Unlikely & Low & Likely & Low \\
\hline & Fish-to-fish contact (including escaped fish) & Unlikely & Medium & Moderate & Medium \\
\hline & Biological vectors (parasites, birds, etc.) & Unlikely & Medium & Moderate & Medium \\
\hline & Equipment and personnel & Unlikely & Low & Likely & Low \\
\hline \multirow[t]{2}{*}{ Consequences } & Spillback infection in wild host & Unlikely & High & Likely & High \\
\hline & Disease in wild population & Unlikely & High & Unlikely & High \\
\hline \multicolumn{6}{|c|}{ (C) Lepeophtheirus salmonis } \\
\hline \multirow{2}{*}{ Introduction } & Infection on farm derived from neighbouring farm & Moderate & Low & Likely & Low \\
\hline & Infection on farm derived from wild reservoir & Moderate & High & Moderate & High \\
\hline \multirow[t]{4}{*}{ Dissemination from farm } & Water & Moderate & Low & Likely & Low \\
\hline & Fish-to-fish contact (including escaped fish) & Unlikely & Medium & Unlikely & Medium \\
\hline & Biological vectors (parasites, birds, etc.) & Rare & Medium & Unlikely & Medium \\
\hline & Equipment and personnel & Unlikely & Low & Unlikely & Low \\
\hline \multirow[t]{2}{*}{ Consequences } & Spillback infection in wild host & Moderate & High & Likely & Low \\
\hline & Disease in wild population & Unlikely & High & Unlikely & High \\
\hline
\end{tabular}


uncertainty. Mitigation measures for SAV are similar to those for ISAV, resulting in a similar pattern in the likelihood and uncertainties of transmission pathways. The occurrence, geographic distribution and genetics of SAV in wild reservoirs, however, lessen the uncertainty of transmission to mariculture (Table 4B). Mitigation of sea lice results in an altered pattern in the likelihood of transmission pathways compared with the viruses: with mitigation there remains an elevated likelihood of sea lice transmission from neighbouring farms since treatments can be less than $100 \%$ effective, even less so when parasites display resistance to the medication (Table 4C). Similarly, the likelihood of sea lice spillback remains moderate, despite treatment.

\section{DISCUSSION AND CONCLUSIONS}

A consistent finding of epidemiological investigations into the transmission of ISAV, SAV and Lepeophtheirus salmonis associated with mariculture is the risk posed to neighbouring farms as a function of distance (Aldrin et al. 2011, Salama \& Murray 2013). The extent of this risk is site or area specific, and dependent on the biomass or density of the affected stock, the shedding rate and half-life of the pathogen and on hydrographic characteristics, which influence patterns of pathogen dispersal and can vary considerably among coastal regions (Suttle \& Chen 1992, Foreman et al. 2012, Garver et al. 2013a, Asplin et al. 2014). These data have been used to estimate zones of risk for sea lice and ISAV, implying that neighbouring farms or any wild fish within defined zones are at elevated risk of exposure to the pathogen (Jarp \& Karlsen 1997, Mardones et al. 2011, Werkman et al. 2011, Serra-Llinares et al. 2014). The consequences of this exposure will be determined by the magnitude and duration of the infectious dose and by factors intrinsic to the at-risk population such as density, age, overall health and natural susceptibility. These factors are relatively well characterised for cultured stock, which are therefore valuable in validating predictions of exposure, infection and possible disease consequences that result from pathogen transmission from neighbouring sites. The likelihood and uncertainty of pathogen transmission pathways were compared with and without farm-based disease mitigation strategies. Infections with ISAV or infectious haematopoietic necrosis virus (IHNV, see Saksida 2006) among maricultured Atlantic salmon tend to be acute with elevated mortality. Outbreaks of these infections trigger management responses which in- clude early pathogen detection through the use of sensitive and specific diagnostic methods followed by cage- or site-specific depopulation. In addition, elevated biosecurity standards, including control over the movement of fish and the movement and disinfection of staff (including clothing and personal equipment) and larger equipment such as transport vehicles, have become widely adopted by industry. As a result, outbreaks of clinical ISA are now rare or absent in Scotland and New Brunswick in eastern Canada and a recent outbreak of IHN in western Canada was of shorter duration with lower mortalities compared with earlier outbreaks (Murray et al. 2010, ICES 2013). It is worth noting a possible difference between the epidemiology of ISAV and SAV. For ISAV, the wild reservoir of the HPR0 strain remains a potentially important source for continued outbreaks, in addition to HPR0 strains that persist in farmed populations (Lyngstad et al. 2011). By contrast, wild reservoirs no longer seem to play a part in the epidemiology of SAV. Biosecurity will minimise the spread of infections, and maintaining a high health status (through good water quality, vaccination, etc.) will minimise the likelihood of future disease emergence. New diseases inevitably have their origin in wild populations, but emergence is generally observed in farmed populations (Fig. 1); thus, a high health status in farmed fish will reduce their susceptibility to putative pathogens in wild populations (and possible subsequent back spill).

In comparison to the viruses, sea lice infections do not elicit similarly robust mitigation measures. Rather, they are readily counted and treatment or other management actions are often linked to parasite abundance relative to a treatment trigger level. Sea lice treatment trigger levels are management thresholds which aim to reduce infection pressure on adjacent farmed or wild host populations (Saksida et al. 2011). Where they exist, infection thresholds are legislated or adopted under industry codes of good practice (Murray 2014), and values differ within and among countries (Ritchie \& Boxaspen 2011). In British Columbia, the adoption of management thresholds led to a transient increase in the quantity of emamectin benzoate used (Saksida et al. 2011). Generally, the increased use of a single medicine increases the risk of resistance in the target population, ultimately lessening the effectiveness of the treatment. Theoretically, to be most effective, trigger thresholds should be adjusted to reflect host biomass in an area (Ritchie \& Boxaspen 2011). More data are required to assess the effectiveness of treatment triggers with respect to sea lice spillback to wild salmon. The continued release of 
sea lice larvae resulting from reduced treatment efficacy and from sub-threshold infections argues for the continued application of integrated pest management strategies (Brooks 2009). The reliability with which sea lice populations in a given region can be screened for sensitivity to treatment chemicals or medicines and alternative treatments applied as required lessens the uncertainty surrounding the effectiveness of these measures.

Whereas epidemiological data from mariculture may be useful in estimating risk of exposure, they are limited in their ability to estimate infection and disease in adjacent wild populations. Thus, while evidence supports the theoretical occurrence of ISAV, SAV and salmon lice within a zone of risk associated with an infected mariculture site, there is little evidence of ISAV or SAV infections in wild fish in support of this claim, which may be a consequence of limited surveillance. Further, there are no data that permit interpretation of the consequences of ISAV or SAV infections in wild fish. The extent to which salmon lice contribute to measurable populationlevel effects is beginning to be explored, but there is uncertainty and spatial variation in the apparent effects (Krkošek et al. 2013). In the treated-smolt studies reported above, the extent to which the apparent louse effect is related to mariculture requires further work.

We have argued that the wealth of epidemiological data derived from salmon mariculture relative to its scarcity from wild populations, provides a reasonable basis for estimating pathogen interactions both among farmed populations and between farmed and wild populations. However, the existence of these data does not always equate with their availability for third party analyses. The following requirements are considered useful and possibly necessary to assist in the characterisation and mitigation of pathogen transmission from farmed salmonids.

(1) Systematic collection of disease-relevant data from cultured populations, including pathogen identification, prevalence, severity and mortality;

(2) Systematic collection of data related to farm species and biomass, seawater temperature and salinity and plankton density;

(3) Archival of mariculture-derived data in an accessible format and establishment of data sharing protocols;

(4) Development and application of coupled hydrodynamic and particle-tracking models to characterise hydrographic processes in mariculture coastal zones to estimate pathogen dispersion from farms or farm clusters;
(5) Establishment of epidemiologically isolated management zones for farm clusters. Management zones should incorporate limits to local biomass, and protocols for coordinated activities such as stocking, disease pathogen monitoring, harvesting, single ageclass and sea lice treatments;

(6) Pathogen surveillance of adjacent wild populations to document marine reservoirs of infection and validate mariculture management practices.

Acknowledgements. The authors are grateful to members of the ICES Expert Group on Pathology and Diseases of Marine Organisms (WGPDMO) and to 3 anonymous reviewers for valuable comments on an earlier draft.

\section{LITERATURE CITED}

Aldrin M, Lyngstad T, Kristoffersen AB, Storvik B, Borgan Ø, Jansen PA (2011) Modelling the spread of infectious salmon anaemia among salmon farms based on seaway distances between farms and genetic relationships between infectious salmon anaemia virus isolates. J R Soc Interface 8:1346-1356

Aldrin M, Storvik B, Kristoffersen AB, Jansen PA (2013) Space-time modelling of the spread of salmon lice between and within Norwegian marine salmon farms. PLoS ONE 8:e64039

Amundrud TL, Murray AG (2009) Modelling sea lice dispersion under varying environmental forcing in a Scottish sea loch. J Fish Dis 32:27-44

Andersen L, Bratland A, Hodneland K, Nylund A (2007) Tissue tropism of salmonid alphaviruses (subtypes SAV 1 and SAV 3) in experimentally challenged Atlantic salmon (Salmo salar L.). Arch Virol 152:1871-1883

Asplin L, Johnsen IA, Sandvik AD, Albretsen J, Sundfjord V, Aure J, Boxaspen K (2014) Dispersion of salmon lice in the Hardangerfjord. Mar Biol Res 10:216-225

Aunsmo A, Valle PS, Sandberg M, Midtlying PJ, Bruheim T (2010) Stochastic modelling of direct costs of pancreas disease (PD) in Norwegian farmed Atlantic salmon (Salmo salar L.). Pre Vet Med 93:233-241

Bang Jensen B, Kristoffersen AB, Myr C, Brun E (2012) Cohort study of effect of vaccination on pancreas disease in Norwegian salmon aquaculture. Dis Aquat Org 102:23-31

Beamish RJ, Neville CM, Sweeting RM, Ambers N (2005) Sea lice on adult Pacific salmon in the coastal waters of Central British Columbia, Canada. Fish Res 76:198-208

Beamish RJ, Neville CM, Sweeting RM, Jones SRM and others (2007) A proposed life history strategy for the salmon louse, Lepeophtheirus salmonis in the subarctic Pacific Ocean. Aquaculture 264:428-440

> Bergh Ø (2007) The dual myths of the healthy wild fish and the unhealthy farmed fish. Dis Aquat Org 75:159-164

$>$ Bjørn PA, Finstad B (2002) Salmon lice, Lepeophtheirus salmonis (Krøyer), infestation in sympatric populations of Arctic charr, Salvelinus alpinus (L.), and sea trout, Salmo trutta (L.), in areas near and distant from salmon farms. ICES J Mar Sci 59:131-139

Bjørn PA, Finstad B, Kristoffersen R (2001) Salmon lice infection of wild sea trout and Arctic char in marine and freshwaters: the effects of salmon farms. Aquacult Res 32:947-962 
Bjørn PA, Sivertsgård R, Finstad B, Nilsen R, Serra-Llinares RM, Kristoffersen R (2011) Area protection may reduce salmon louse infection risk to wild salmonids. Aquacult Environ Interact 1:233-244

- Boucher P, Baudin-Laurencin F (1996) Sleeping disease and pancreas disease: comparative histopathology and acquired cross-protection. J Fish Dis 19:303-310

Boucher P, Raynard RS, Houghton G, Baudin-Laurencin F (1995) Comparative experimental transmission of pancreas disease in Atlantic salmon, rainbow trout and brown trout. Dis Aquat Org 22:19-24

Brandal PO, Egidius E (1977) Preliminary report on oral treatment against salmon lice, Lepeophtheirus salmonis, with Neguvon. Aquaculture 10:177-178

Bron JE, Sommerville C, Wootten R, Rae GH (1993) Fallowing of marine Atlantic salmon, Salmo salar L., farms as a method for the control of sea lice, Lepeophtheirus salmonis (Kroyer 1837). J Fish Dis 16:487-493

Brooks KM (2009) Considerations in developing an integrated pest management programme for control of sea lice on farmed salmon in Pacific Canada. J Fish Dis 32: 59-73

Brown DT, Condreay LD (1986) Replication of alphaviruses in mosquito cells. In: Schlesinger S, Schlesinger MJ (eds) The Togaviridae and Flaviviridae (the viruses). Springer, New York, NY, p 171-207

$>$ Bruno DW, Noguera PA, Black J, Murray W, Macqueen DJ, Matejusova I (2014) Identification of a wild reservoir of salmonid alphavirus in common dab Limanda limanda with emphasis on virus culture and sequencing. Aquacult Environ Interact 5:89-98

> Chaput G (2012) Overview of the status of Atlantic salmon (Salmo salar) in the North Atlantic and trends in marine mortality. ICES J Mar Sci 69:1538-1548

Christiansen DH, Østergaard PS, Snow M, Dale OB, Falk K (2011) A low-pathogenic variant of infectious salmon anaemia virus (ISAV-HPR0) is highly prevalent and causes a non-clinical transient infection in farmed Atlantic salmon (Salmo salar L.) in the Faroe Islands. J Gen Virol 92:909-918

> Christie KE, Graham DA, McLoughlin MF, Villoing S, Todd D, Knappskog D (2007) Experimental infection of Atlantic salmon Salmo salar pre-smolts by i.p. injection with new Irish and Norwegian salmonid alphavirus (SAV) isolates: a comparative study. Dis Aquat Org 75:13-22

Cipriano R (2009) Antibody against infectious salmon anaemia virus among feral Atlantic salmon (Salmo salar). ICES J Mar Sci 66:865-870

> Cook PF, McBeath SJ, Bricknell IR, Bron JE (2010) Determining the age of individual Lepeophtheirus salmonis (Krøyer, 1837) copepodids by measuring stored lipid volume: proof of principle. J Microsc 240:83-86

Costello MJ (2009) The global economic cost of sea lice to the salmonid farming industry. J Fish Dis 32:115-118

Devold M, Krossøy B, Aspehaug V, Nylund A (2000) Use of RT-PCR for diagnosis of infectious salmon anaemia virus (ISAV) in carrier sea trout Salmo trutta after experimental infection. Dis Aquat Org 40:9-18

$>$ EFSA (European Food and Safety Authority) (2006) Scientific report on migratory birds and their possible role in the spread of highly pathogenic avian influenza. EFSA J 357:1-46

> EFSA (European Food and Safety Authority) (2012) Scientific opinion on infectious salmon anaemia. EFSA J 10:2971

> Elliott M, O'Reilly MGO, Taylor CJL (1990) The forth estuary: a nursery and overwintering area for North Sea fishes. Hydrobiologia 195:89-103
FAO (Food and Agriculture Organisation of the United Nations (2012) FishstatJ, a tool for fishery statistics analysis. FAO, Fisheries and Aquaculture Department, Rome. www.fao.org/fishery/statistics/software/fishstatj/en

Ford JS, Myers RA (2008) A global assessment of salmon aquaculture impacts on wild salmonids. PLoS Biol 6:e33

Foreman MGG, Stucchi DJ, Garver KA, Tuele D and others (2012) A circulation model for the Discovery Islands, British Columbia. Atmos-ocean 50:301-316

Fringuelli E, Rowley HM, Wilson JC, Hunter R, Rodger $\mathrm{H}_{\text {, }}$ Graham DA (2008) Phylogenetic analyses and molecular epidemiology of European salmonid alphaviruses (SAV) based on partial E2 and nsP3 nucleotide sequences. J Fish Dis 31:811-823

> Gargan PG, Forde G, Hazon N, Russell DJF, Todd CD (2012) Evidence for sea lice-induced marine mortality of Atlantic salmon (Salmo salar) in western Ireland from experimental releases of ranched smolts treated with emamectin benzoate. Can J Fish Aquat Sci 69:343-353

- Garver KA, Mahony AAM, Stucchi D, Richard J, van Woensel C (2013a) Estimation of parameters influencing waterborne transmission of infectious hematopoietic necrosis virus (IHNV) in Atlantic salmon (Salmo salar). PLoS ONE 8:e82296

> Garver KA, Traxler GS, Hawley LM, Richard J, Ross JP, Lovy J (2013b) Molecular epidemiology of viral haemorrhagic septicaemia virus (VHSV) in British Columbia, Canada, reveals transmission from wild to farmed fish. Dis Aquat Org 104:93-104

Gillibrand PA, Kate JW (2007) Dispersal of sea louse larvae from salmon farms: modelling the influence of environmental conditions and larval behaviour. Aquat Biol 1:63-75

> Graham DA, Jewhurst HL, McLoughlin MF, Rowley HM, Sourd P, Taylor C, Todd D (2006) Sub-clinical infection of farmed Atlantic salmon Salmo salar with salmonid alphavirus - a prospective longitudinal study. Dis Aquat Org 72:193-199

- Graham DA, Staples C, Wilson CJ, Jewhurst H, Cherry K, Gordon A, Rowley HM (2007) Biophysical properties of salmonid alphaviruses: influence of temperature and $\mathrm{pH}$ on virus survival. J Fish Dis 30:533-543

> Graham DA, Fringuelli E, Wilson C, Rowley HM and others (2010) Prospective longitudinal studies of salmonid alphavirus infections on two Atlantic salmon farms in Ireland; evidence for viral persistence. J Fish Dis 33: 123-135

Graham DA, Fringuelli E, Rowley HM, Cockerill D and others (2012) Geographical distribution of salmonid alphavirus subtypes in marine farmed Atlantic salmon, Salmo salar L., in Scotland and Ireland. J Fish Dis 35:755-765

> Green DM (2010) A strategic model for epidemic control in aquaculture. Prev Vet Med 94:119-127

Gustafson LL, Ellis SS, Beattie MJ, Chang BD and others (2007) Hydrographics and the timing of infectious salmon anemia outbreaks among Atlantic salmon (Salmo salar L.) farms in the Quoddy region of Maine, USA and New Brunswick, Canada. Prev Vet Med 78:35-56

Hammell KL, Dohoo IR (2005) Risk factors associated with mortalities attributed to infectious salmon anaemia virus in New Brunswick, Canada. J Fish Dis 28:651-661

Hamre LA, Eichner C, Caipang CMA, Dalvin ST and others (2013) The salmon louse Lepeophtheirus salmonis (Copepoda: Caligidae) life cycle has only two chalimus stages. PLoS ONE 8:e73539

Håstein T, Lindstad T (1991) Diseases in wild and cultured salmon: possible interaction. Aquaculture 98:277-288 
Hedrick RP (1998) Relationships of the host, pathogen, and environment: implications for diseases of cultured and wild fish populations. J Aquat Anim Health 10:107-111

Helgesen KO, Bravo S, Sevatdal S, Mendoza J, Horsberg TE (2014) Deltamethrin resistance in the sea louse Caligus rogercresseyi (Boxhall and Bravo) in Chile: bioassay results and usage data for antiparasitic agents with references to Norwegian conditions. J Fish Dis, doi:10.1111/ jfd. 12223

Heuch PA, Revie CW, Gettinby G (2003) A comparison of epidemiological patterns of salmon lice, Lepeophtheirus salmonis, infections on farmed Atlantic salmon, Salmo salar L., in Norway and Scotland. J Fish Dis 26:539-551

> Heuch PA, Bjørn PA, Finstad B, Holst JC, Asplin L, Nilsen F (2005) A review of the Norwegian 'National Action Plan Against Salmon Lice on Salmonids': the effect on wild salmonids. Aquaculture 246:79-92

> Heuch PA, Olsen RS, Malkenes R, Revie CW and others (2009) Temporal and spatial variations in lice numbers on salmon farms in the Hardanger fjord 2004-06. J Fish Dis 32:89-100

Hjortaas MJ, Skelstad HR, Taksdal T, Olsen B and others (2013) The first detections of subtype 2-related salmonid alphavirus (SAV2) in Atlantic salmon, Salmo salar L., in Norway. J Fish Dis 36:71-74

ICES (2013) Report of the working group on pathology and diseases of marine organisms (WGPDMO), 5-9 March 2013, Padova, Italy. ICES CM 2013/SSGHIE:03. ICES, Copenhagen

> Jackson D, Cotter D, Newell J, McEvoy S and others (2013a) Impact of Lepeophtheirus salmonis infestations on migrating Atlantic salmon smolts at eight locations in Ireland with an analysis of lice induced marine mortality. J Fish Dis 36:273-281

Jackson D, Kane F, O'Donohoe P, McDermott T, Kelly S, Drumm A, Newell J (2013b) Sea lice levels on wild Atlantic salmon, Salmo salar L., returning to the coast of Ireland. J Fish Dis 36:293-298

> Jansen MD, Taksdal T, Wasmuth MA, Gjerset B and others (2010) Salmonid alphaviruses (SAV) and pancreas disease (PD) in Atlantic salmon, Salmo salar L., in freshwater and seawater sites in Norway from 2006-2009. J Fish Dis 33:391-402

> Jansen PA, Kristoffersen AB, Viljugrein H, Jimenez D, Aldrin M, Stien A (2012) Sea lice as a density-dependent constraint to salmonid farming. Proc R Soc Lond B Biol Sci 279:2330-2338

> Jansen MD, Jensen BB, Brun E (2014) Clinical manifestations of pancreas disease outbreaks in Norwegian marine salmon farming-variations due to salmonid alphavirus subtype. J Fish Dis, doi:10.1111/jfd.12238

> Jarp J, Karlsen E (1997) Infectious salmon anaemia (ISA) risk factors in sea-cultured Atlantic salmon Salmo salar. Dis Aquat Org 28:79-86

Johansen LH, Jensen I, Mikkelsen H, Bjørn PA, Jansen PA, Bergh $\varnothing$ (2011) Disease interactions and pathogen exchange between wild and farmed populations with special reference to Norway. Aquaculture 315:167-186

Johnson SC, Treasurer JW, Bravo S, Nagasawa K, Kabata Z (2004) A review of the impact of parasitic copepods on marine aquaculture. Zool Stud 43:229-243

Jones SRM (2009) Controlling salmon lice on farmed salmon and implications for wild salmon. CAB Rev Perspect Agricult Vet Sci Nutr Nat Resourc 4:1-13

> Jones SRM, Groman DB (2001) Cohabitation transmission of infectious salmon anaemia virus among freshwaterreared Atlantic salmon (Salmo salar). J Aquat Anim
Health 13:340-346

Jones SRM, Hargreaves NB (2009) Infection threshold to estimate Lepeophtheirus salmonis-associated mortality among juvenile pink salmon. Dis Aquat Org 84:131-137

Jones SRM, MacKinnon AM, Groman DB (1999a) Virulence and pathogenicity of infectious salmon anemia virus isolated from farmed salmon in Atlantic Canada. J Aquat Anim Health 11:400-405

Jones SRM, MacKinnon AM, Salonius K (1999b) Vaccination of freshwater-reared Atlantic salmon reduces mortality associated with infectious salmon anaemia virus. Bull Eur Assoc Fish Pathol 19:98-101

> Karlsen M, Tingbo T, Solbakk IT, Evenson O, Furevik A, Aas-Eng A (2012) Efficacy and safety of an inactivated vaccine against salmonid alphavirus (Family Togaviridae). Vaccine 30:5688-5694

Karlsen M, Gjerset B, Hansen T, Rambaut A (2014) Multiple introductions of salmonid alphavirus from a wild reservoir have caused independent and self-sustainable epizootics in aquaculture. J Gen Virol 95:52-59

Kibenge FSB, Munir K, Kibenge MJT, Joseph T, Moneke E (2004) Infectious salmon anemia virus: causative agent, pathogenesis and immunity. Anim Health Res Rev 5: $65-78$

> Kibenge FSB, Godoy MG, Fast M, Workenhe S, Kibenge MJT (2012) Counter measures against viral diseases of farmed fish. Antiviral Res 95:257-281

Kongtorp RT, Stene A, Andreassen PA, Aspehaug V and others (2010) Lack of evidence for vertical transmission of SAV 3 using gametes of Atlantic salmon, Salmo salar L., exposed by natural and experimental routes. J Fish Dis 33:879-888

Kristoffersen AB, Viljugrein H, Kongtorp RT, Brun E, Jansen PA (2009) Risk factors for pancreas disease (PD) outbreaks in farmed Atlantic salmon and rainbow trout in Norway during 2003-2007. Prev Vet Med 90:127-136

Kristoffersen AB, Rees EE, Stryhn H, Ibarra R, Campisto JL, Revie CW, St-Hilaire S (2013) Understanding sources of sea lice for salmon farms in Chile. Prev Vet Med 111: 165-175

Krkošek M, Lewis MA, Volpe JP (2005) Transmission dynamics of parasitic sea lice from farm to wild salmon. Proc R Soc Lond B Biol Sci 272:689-696

Krkošek M, Ford JS, Morton A, Lele S, Myers RA, Lewis MA (2007) Declining wild salmon populations in relation to parasites from farm salmon. Science 318:1772-1775

Krkošek M, Connors BM, Morton A, Lewis MA, Dill LM, Hilborn R (2011) Effects of parasites from salmon farms on productivity of wild salmon. Proc Natl Acad Sci USA 108:14700-14704

Krkošek M, Revie CW, Gargan PG, Skilbrei OT, Finstad B, Todd CD (2013) Impact of parasites on salmon recruitment in the northeast Atlantic Ocean. Proc R Soc Lond B Biol Sci, doi:10.1098/rspb.2012.2359

Kurath G, Winton J (2011) Complex dynamics at the interface between wild and domestic viruses of finfish. Curr Opin Virol 1:73-80

> LeBlanc F, Arseneau JR, Leadbeater S, Glebe B, Laflamme M, Gagné N (2012) Transcriptional response of Atlantic salmon (Salmo salar) after primary versus secondary exposure to infectious salmon anemia virus (ISAV). Mol Immunol 51:197-209

Lees F, Gettinby G, Revie CW (2008) Changes in epidemiological patterns of sea lice infestation on farmed Atlantic salmon, Salmo salar L., in Scotland between 1996 and 2006. J Fish Dis 31:259-268

Lester K, Black J, Bruno DW (2011) Prevalence and phylo- 
genetic analysis of salmonid alphavirus in Scottish fish farms from 2000-2009. Bull Eur Assoc Fish Pathol 31: 199-202

Lyngstad TM, Jansen PA, Sindre H, Jonassen CM, Hjortaas MJ, Johnsen S, Brun E (2008) Epidemiological investigation of infectious salmon anaemia (ISA) outbreaks in Norway 2003-2005. Prev Vet Med 84:213-227

Lyngstad TM, Hjortaas MJ, Kristoffersen AB, Markussen T, Karlsen ET, Jonassen CM, Jansen PA (2011) Use of molecular epidemiology to trace transmission pathways for infectious salmon anaemia virus (ISAV) in Norwegian salmon farming. Epidemics 3:1-11

Lyngstad T, Tavornpanich S, Brun E (2013) Appendix task 3: disease characterization-infectious salmon anaemia (ISA). EFSA Support Pub EN-442:53-61

> Madhun AS, Karlsbakk E, Isachsen CH, Omdal LM and others (2014) Potential disease interaction reinforced: double-virus-infected escaped farmed Atlantic salmon, Salmo salar L., recaptured in a nearby river. J Fish Dis, doi:10.1111/jfd.12228

> Mardones FO, Perez AM, Carpenter TE (2009) Epidemiologic investigation of the re-emergence of infectious salmon anemia virus in Chile. Dis Aquat Org 84:105-114

Mardones FO, Perez AM, Valdes-Donoso P, Carpenter TE (2011) Farm-level reproduction number during an epidemic of infectious salmon anemia virus in southern Chile in 2007-2009. Prev Vet Med 102:175-184

Mardones FO, Martinez-Lopez B, Valdes-Donoso P, Carpenter TE, Perez AM (2014) The role of fish movements and the spread of infectious salmon anemia virus (ISAV) in Chile, 2007-2009. Prev Vet Med 114:37-46

- Marshall SH, Ramirez R, Labra A, Carmona M, Munoz C (2014) Bona fide evidence for natural vertical transmission of infectious salmon anemia virus in freshwater brood stocks of farmed Atlantic salmon (Salmo salar) in Southern Chile. J Virol 88:6012-6018

- Marty GD, Saksida SM, Quinn TJ II (2010) Relationship of farm salmon, sea lice and wild salmon populations. Proc Natl Acad Sci USA 107:22599-22604

McCleary S, Giltrap M, Henshilwood K, Ruane NM (2014) Detection of salmonid alphavirus RNA in Celtic and Irish Sea flatfish. Dis Aquat Org 109:1-7

> McClure CA, Hammell KL, Dojoo IR, Gagne N (2004) Lack of evidence of infectious salmon anemia virus in pollock Pollachius virens cohabiting with infected farmed Atlantic salmon Salmo salar. Dis Aquat Org 61:149-152

> McClure CA, Hammell KL, Dohoo IR (2005) Risk factors for outbreaks of infectious salmon anemia in farmed Atlantic salmon. Prev Vet Med 72:263-280

> McKenzie E, Gettinby G, McCart K, Revie CW (2004) Timeseries models of sea lice Caligus elongatus (Nordmann) abundance on Atlantic salmon Salmo salar L. in Loch Sunart, Scotland. Aquacult Res 35:764-772

> McKibben MA, Hay DW (2004) Distributions of planktonic sea lice larvae Lepeophtheirus salmonis in the inter-tidal zone in Loch Torridon, western Scotland in relation to salmon farm production cycles. Aquacult Res 35:742-750

McLoughlin MF, Graham DA (2007) Alphavirus infections in salmonids - a review. J Fish Dis 30:511-531

McLoughlin MF, Nelson RT, Rowley HM, Cox DI, Grant AN (1996) Experimental pancreas disease in Atlantic salmon Salmo salar post-smolts induced by salmon pancreas disease virus (SPDV). Dis Aquat Org 26:117-124

McLoughlin MF, Peeler E, Foyle KL, Rodger HD, O'Ceallachain D, Geoghegan F (2003) An epidemiological investigation of the re-emergence of pancreas disease in Irish farmed Atlantic salmon (Salmo salar L.) in 2002.
Marine Environment and Health Series No. 14, Marine Institute, Oranmore

McVicar AH (1997) Disease and parasite implications of the coexistence of wild and cultured Atlantic salmon populations. ICES J Mar Sci 54:1093-1103

Melville KJ, Griffiths SG (1999) Absence of vertical transmission of infectious salmon anemia virus (ISAV) from individually infected Atlantic salmon Salmo salar. Dis Aquat Org 38:231-234

Middlemas SJ, Raffell JA, Hay DW, Hatton-Ellis M, Armstrong JD (2010) Temporal and spatial patterns of sea lice on sea trout in western Scotland in relation to fish farm production cycles. Biol Lett 6:548-551

Middlemas SJ, Fryer RJ, Tulett D, Armstrong JD (2013) Relationship between sea lice levels on sea trout and fish farm activity in western Scotland. Fish Manag Ecol 20: 68-74

> Mordue (Luntz) AJ, Birkett MA (2009) A review of host finding behaviour in the parasitic sea louse, Lepeophtheirus salmonis (Caligidae: Copepoda). J Fish Dis 32:3-13

Morton A, Routledge R, Peet C, Ladwig A (2004) Sea lice (Lepeophtheirus salmonis) infection rates on juvenile pink (Oncorhynchus gorbuscha) and chum (Oncorhynchus keta) salmon in the nearshore marine environment of British Columbia, Canada. Can J Fish Aquat Sci 61: 147-157

Munro ALS, Ellis AE, McVicar AH, McLay AH, Needham EA (1984) An exocrine pancreas disease of farmed Atlantic salmon in Scotland. Helgol Meeresunters 37: 571-586

> Munro PD, Murray AG, Fraser DI, Peeler J (2003) An evaluation of the risk of infectious salmon anaemia transmission associated with different salmon harvesting methods in Scotland. Ocean Coast Manag 46:157-174

Murray AG (2009) Using simple models to review the application and implications of different approaches used to simulate transmission of pathogens among aquatic animals. Prev Vet Med 88:167-177

> Murray AG (2013) Epidemiology of the spread of viral diseases under aquaculture. Curr Opin Virol 3:74-78

Murray AG (2014) A note on sea lice abundance on farmed Atlantic salmon in Scotland 2011-2013: significant regional and seasonal variation. Aquacult Res, doi:10.1111/ are.12554

> Murray AG, Gillibrand PA (2006) Modelling salmon lice dispersal in Loch Torridon, Scotland. Mar Pollut Bull 53:128-135

Murray AG, Peeler EJ (2005) A framework for understanding the potential for emerging diseases in aquaculture. Prev Vet Med 67:223-235

Murray AG, Smith RJ, Stagg RM (2002) Shipping and the spread of infectious salmon anaemia in Scottish aquaculture. Emerg Infect Dis 8:1-5

Murray AG, Munro LA, Wallace IS, Berx B, Pendrey D, Fraser D, Raynard RS (2010) Epidemiological investigation into the re-emergence and control of an outbreak of infectious salmon anaemia in the Shetland Islands, Scotland. Dis Aquat Org 91:189-200

Murray AG, Amundrud TL, Penston MJ, Pert CC, Middlemas SJ (2011) Abundance and distribution of larval sea lice in Scottish coastal waters. In: Jones SRM, Beamish RJ (eds) Salmon lice: an integrated approach to understanding parasite abundance and distribution. Blackwell Publishing, Chichester, p 51-82

Noakes DJ, Beamish RJ, Kent ML (2000) On the decline of Pacific salmon and speculative links to salmon farming in British Columbia. Aquaculture 183:363-386 
Nowak BF (2007) Parasitic diseases in marine cage culture-an example of experimental evolution of parasites? Int J Parasitol 37:581-588

Nylund A, Devold M, Plarre H, Isdal E, Arseth M (2003) Emergence and maintenance of infectious salmon anaemia virus (ISAV) in Europe: a new hypothesis. Dis Aquat Org 56:11-24

Nylund A, Plarre H, Karlsen M, Fridell F, Ottem KF, Bratland A, Sæther PA (2007) Transmission of infectious salmon anaemia virus (ISAV) in farmed populations of Atlantic salmon (Salmo salar). Arch Virol 152:151-179

O'Donohoe P, Kane F, Kelly S, McDermott T, Drumm A, Jackson D (2013) National survey of sea lice (Lepeophtheirus salmonis Krøyer and Caligus elongatus Nordmann) on fish farms in Ireland-2012. Irish Fisheries Bull No 31. Marine Institute, Oranmore

Ögüt H, LaPatra S, Reno PW (2005) Effects of host density on furunculosis epidemics determined by the simple SIR model. Prev Vet Med 71:83-90

Oidtmann B, Peeler E, Thrush M, Pearce F and others (eds) (2013) Project 'Risk Categorisation for Aquatic Animal Health Surveillance'. EFSA Suppl Publ EN-442, EFSA, Parma

Parrish DL, Behnke RJ, Gephard SR, McCormick SD, Reeves SR (1998) Why aren't there more Atlantic salmon (Salmo salar)? Can J Fish Aquat Sci 55(S1):281-287

> Peacock SJ, Krkošek M, Proboszcz S, Orr C, Lewis MA (2013) Cessation of a salmon decline with control of parasites. Ecol Appl 23:606-620

Peeler EJ, Murray AG, Thebault A, Brun E, Giovaninni A, Thrush MA (2007) The application of risk analysis in aquatic animal health management. Prev Vet Med 81: $3-20$

> Penston MJ, Davies IM (2009) An assessment of salmon farms and wild salmonids as sources of Lepeophtheirus salmonis (Krøyer) copepodids in the water column in Loch Torridon, Scotland. J Fish Dis 32:75-88

Penston MJ, Millar CP, Zuur A, Davies IM (2008) Spatial and temporal distribution of Lepeophtheirus salmonis (Kroyer) larvae in a sea loch containing Atlantic salmon, Salmo salar L., farms on the northwest coast of Scotland. J Fish Dis 31:361-371

> Penston MJ, McBeath AJA, Millar CP (2011) Densities of planktonic Lepeophtheirus salmonis before and after an Atlantic salmon farm relocation. Aquacult Environ Interact $1: 225-232$

> Pert CC, Fryer RJ, Cook P, Kilburn R and others (2014) Using sentinel cages to estimate infection pressure on salmonids from sea lice in Loch Sheildaig, Scotland. Aquacult Environ Interact 5:49-59

> Petterson E, Sandberg M, Santi N (2009) Salmonid alphavirus associated with Lepeophtheirus salmonis (Copepoda: Caligidae) from Atlantic salmon, Salmo salar. J Fish Dis 32:477-479

Pike AW, Wadsworth SL (1999) Sea lice on salmonids: their biology and control. Adv Parasitol 44:233-337

- Plarre H, Devold M, Snow M, Nylund A (2005) Prevalence of infectious salmon anaemia virus (ISAV) in wild salmonids in western Norway. Dis Aquat Org 66:71-79

Pulkkinen K, Suomalainen LR, Read AF, Ebert D, Rintamäki P, Valtonen ET (2010) Intensive fish farming and the evolution of pathogen virulence: the case of columnaris disease in Finland. Proc R Soc Lond B Biol Sci 277: 593-600

Raynard RS, Murray AG, Gregory A (2001) Infectious salmon anaemia virus in wild fish from Scotland. Dis Aquat Org 46:93-100
Raynard RS, Wahli T, Vatsos I, Mortensen S (2007) Review of disease interaction and pathogen exchange between farmed and wild finfish and shellfish in Europe. Marine Scotland Science, Aberdeen. www.revistaaquatic.com/ DIPNET/

- Revie CW, Gettinby G, Treasurer JW, Rae GH, Clark N (2002) Temporal, environmental and management factors influencing the epidemiological patterns of sea lice (Lepeophtheirus salmonis) infestations on farmed Atlantic salmon (Salmo salar L.) in Scotland. Pest Manag Sci 58: 576-584

Revie CW, Gettinby G, Treasurer JW, Wallace C (2003) Identifying epidemiological factors affecting sea lice Lepeophtheirus salmonis abundance on Scottish salmon farms using general linear models. Dis Aquat Org 57: 85-95

Revie CW, Robbins C, Gettinby G, Kelly L, Treasurer JW (2005) A mathematical model of the growth of sea lice, Lepeophtheirus salmonis, populations on farmed Atlantic salmon, Salmo salar L., in Scotland and its use in the assessment of treatment strategies. J Fish Dis 28:603-613

Riley SC, Munkittrick KR, Allison NE, Krueger CC (2008) Understanding the ecology of disease in Great Lakes fish populations. Aquat Ecosyst Health Manag 11:321-334

Rimstad E, Dale OB, Dannevig BH, Falk K (2011) Infectious salmon anaemia. In: Woo PTK, Bruno DW (eds) Fish diseases and disorders, Vol 3: viral, bacterial and fungal infections, 2nd edn. CAB International, Wallingford, p 143-165

Ritchie G, Boxaspen K (2011) Salmon louse management on farmed salmon-Norway. In: Jones SRM, Beamish RJ (eds) Salmon lice: an integrated approach to understanding parasite abundance and distribution. Blackwell Publishing, Chichester, p 153-176

Ritchie RJ, McDonald JT, Glebe B, Young-Lai E, Johnson E, Gagné N (2009) Comparative virulence of infectious salmon anaemia virus isolates in Atlantic salmon, Salmo salar L. J Fish Dis 32:157-171

Roger HD, Mitchell S (2007) Epidemiological observations of pancreas disease of farmed Atlantic salmon, Salmo salar L., in Ireland. J Fish Dis 30:157-167

> Rogers LA, Peacock SJ, McKenzie P, DeDominicis S and others (2013) Modeling parasite dynamics on farmed salmon for precautionary conservation management of wild salmon. PLoS ONE 8:e60096

Rolland JB, Winton JR (2003) Relative resistance of Pacific salmon to infectious salmon anaemia virus. J Fish Dis 26:511-520

Saksida SM (2006) Infectious haematopoietic necrosis epidemic (2001 to 2003) in farmed Atlantic salmon Salmo salar in British Columbia. Dis Aquat Org 72:213-223

Saksida S, Karreman GA, Constantine J, Donald A (2007) Differences in Lepeophtheirus salmonis abundance levels on Atlantic salmon farms in the Broughton Archipelago, British Columbia, Canada. J Fish Dis 30:357-366

Saksida SM, Morrison D, Sheppard M, Keith I (2011) Sea lice management on salmon farms in British Columbia, Canada. In: Jones SRM, Beamish RJ (eds) Salmon lice: an integrated approach to understanding parasite abundance and distribution. Blackwell Publishing, Chichester, p 235-278

Salama NKG, Murray AG (2011) Farm size as a factor in hydrodynamic transmission of pathogens in aquaculture fish production. Aquacult Environ Interact 2:61-74

Salama NK, Murray AG (2013) A comparison of modelling approaches to access the transmission of pathogens between Scottish fish farms: the role of hydrodynamics 
and site biomass. Prev Vet Med 108:285-293

Salama NKG, Rabe B (2013) Developing models for investigating the environmental transmission of diseasecausing agents within open-cage salmon aquaculture. Aquacult Environ Interact 4:91-115

Salama NKG, Collins CM, Fraser JG, Dunn J, Pert CC, Murray AG, Rabe B (2013) Development and assessment of a biophysical dispersal model for sea lice. J Fish Dis 36: 323-337

Serra-Llinares RM, Bjørn PA, Finstad B, Nilsen R, Harbitz A, Berg M, Asplin L (2014) Salmon lice infection on wild salmonds in marine protected areas: an evaluation of the Norwegian 'National Salmon Fjords'. Aquacult Environ Interact 5:1-16

Skaala Ø, Sjøtun K, Dahl E, Husa V, Bjørge A (2014a) Interactions between salmon farming and the ecosystem: lessons from the Hardangerfjord, western Norway. Mar Biol Res 10:199-202

Skaala Ø, Kålås S, Borgstrøm R (2014b) Evidence of salmon lice-induced mortality of anadromous brown trout (Salmo trutta) in the Hardangerfjord, Norway. Mar Biol Res 10:279-288

Skilbrei OT, Finstad B, Urdal K, Bakke G, Kroglund F, Strand R (2013) Impact of early salmon louse, Lepeophtheirus salmonis, infestation and differences in survival and marine growth of sea-ranched Atlantic salmon, Salmo salar L., smolts 1997-2009. J Fish Dis 36:249-260

Snow M, Black J, Matejusova I, McIntosh R, Baretto E, Wallace IS, Bruno DW (2010) Detection of salmonid alpha virus RNA in wild marine fish: implications for the origins of salmon pancreas disease in aquaculture. Dis Aquat Org 91:177-188

Stene A, Viljurgrein $H$, Yndestad $H$, Tavornpanich $S_{\text {, }}$ Skjerve E (2014) Transmission dynamics of pancreas disease (PD) in a Norwegian fjord: aspects of water transport, contact networks and infection pressure among salmon farms. J Fish Dis 37:123-134

Stien A, Bjørn PA, Heuch PA, Elston DA (2005) Population dynamics of salmon lice Lepeophtheirus salmonis on Atlantic salmon and sea trout. Mar Ecol Prog Ser 290: 263-275

Stucchi DJ, Guo M, Foreman MGG, Czajko P, Galbraith M, Mackas DL, Gillibrand PA (2011) Modeling sea lice production and concentrations in the Broughton Archipelago, British Columbia. In: Jones SRM, Beamish RJ (eds) Salmon lice: an integrated approach to understanding parasite abundance and distribution. Blackwell Publishing, Chichester, p 117-150

Suttle CA, Chen F (1992) Mechanisms and rates of decay of marine viruses in seawater. Appl Environ Microbiol 58: 3721-3729

Thorstad EB, Forseth T (2010) Status of Norwegian salmon stocks in 2010 (in Norwegian). Norsk Institutt for Naturforskning, Trondheim, www.nina.no/archive

Thorud K, Djupvik HO (1988) Infectious salmon anaemia in Atlantic salmon (Salmo salar L.). Bull Eur Assoc Fish Pathol 8:109-111

Todd CD, Walker AM, Hoyle JE, Northcott SJ, Walker AF,

Editorial responsibility: Bengt Finstad,

Trondheim, Norway
Ritchie MG (2000) Infestations of wild adult Atlantic salmon (Salmo salar L.) by the ectoparasitic copepod sea louse Lepeophtheirus salmonis Krøyer: prevalence, intensity and the spatial distribution of males and females on the host fish. Hydrobiologia 429:181-196

Torrissen O, Jones S, Asche F, Guttormsen A and others (2013) Salmon lice-impact on wild salmonids and salmon aquaculture. J Fish Dis 36:171-194

> Totland GK, Hjeltnes BK, Flood PR (1996) Transmission of infectious salmon anaemia (ISA) through natural secretions and excretions from infected smolts of Atlantic salmon Salmo salar during their presymptomatic phase. Dis Aquat Org 26:25-31

- Tully O, Nolan DT (2002) A review of the population biology and host-parasite interactions of the sea louse Lepeophtheirus salmonis (Copepoda: Caligidae). Parasitology 124:S165-S182

> Tully O, Whelan KF (1993) Production of nauplii of Lepeophtheirus salmonis (Krøyer) (Copepoda: Caligidae) from farmed and wild salmon and its relation to the infestation of wild sea trout (Salmo trutta L.) off the west coast of Ireland in 1991. Fish Res 17:187-200

Tully O, Gargan P, Poole WR, Whelan KF (1999) Spatial and temporal variation in the infestation of sea trout (Salmo trutta L.) by the caligid copepod Lepeophtheirus salmonis (Krøyer) in relation to sources of infection in Ireland. Parasitology 119:41-51

Uglem I, Dempster T, Bjørn PA, Sanchez-Jerez P, Økland F (2009) High connectivity of salmon farms revealed by aggregation, residence and repeated movements of wild fish among farms. Mar Ecol Prog Ser 384:251-260

- Vike S, Nylund S, Nylund A (2009) ISA virus in Chile: evidence of vertical transmission. Arch Virol 154:1-8

> Viljugrein H, Staalstrøm A, Molvær J, Urke HA, Jansen PA (2009) Integration of hydrodynamics into a statistical model on the spread of pancreas disease (PD) in salmon farming. Dis Aquat Org 88:35-44

Wallace IS, Gregory A, Murray AG, Munro ES, Raynard RS (2008) Distribution of infectious pancreatic necrosis virus (IPNV) in wild marine fish in Scottish waters with respect to clinically infected aquaculture sites producing Atlantic salmon, Salmo salar L. J Fish Dis 31:177-186

> Werkman M, Green DM, Murray AG, Turnbull JF (2011) The effectiveness of fallowing strategies in disease control in salmon aquaculture assessed with an SIS model. Prev Vet Med 98:64-73

> Weston JH, Welsh MD, McLoughlin MF, Todd D (1999) Salmon pancreas disease virus, an alphavirus infecting farmed Atlantic salmon, Salmo salar L. Virology 256: 188-195

> Weston JH, Graham DA, Branson E, Rowley HM and others (2005) Nucleotide sequence variation in salmonid alphaviruses from outbreaks of salmon pancreas disease and sleeping disease. Dis Aquat Org 66:105-111

Wootten R, Smith JW, Needham EA (1982) Aspects of the biology of the parasitic copepods Lepeophtheirus salmonis and Caligus elongatus on farmed salmonids, and their treatment. Proc R Soc Edinb B Biol Sci 81:185-197

Submitted: June 16, 2014; Accepted: November 11, 2014

Proofs received from author(s): December 20, 2014 